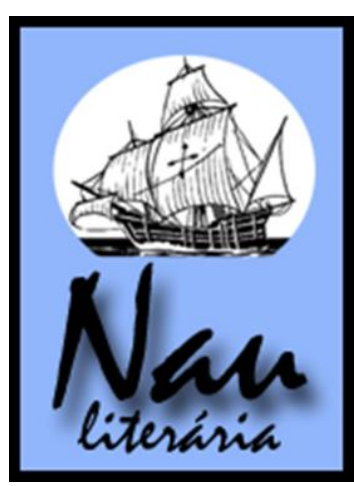

\title{
Estilhaços da catástrofe: apontamentos sobre o exílio em Amores Exilados
}

\section{Glauciane Reis Teixeira*}

\begin{abstract}
Resumo: $\mathrm{O}$ século $\mathrm{XX}$, considerado por Eric Hobsbawn como a "era das catástrofes", tanto na Europa quanto na América Latina, foi o palco onde os mais cruéis atos de violência e autoritarismo encenaram suas tragédias. A ditadura militar, no Brasil, protagonizou atrocidades hediondas por meio da imposição de um regime político que baniu a liberdade, impôs normas rígidas de comportamento ditadas pelo Estado e puniu os indivíduos adversos às regras de poder de diferentes modos, especialmente por meio da prática do exílio. Forma de desenraizamento traumático, no qual se nega a identidade através da ruptura brutal com os referenciais geográficos, sociais e individuais; esta é uma experiência ligada a processos políticos que na dimensão subjetiva implica em aniquilamentos, fragmentações, desorientações e crises identitárias. O romance Amores Exilados (2011), de Godofredo de Oliveira Neto, articula escrita imaginativa e teor testemunhal ao construir uma narrativa alicerçada sobre o sofrimento experimentado pelas vítimas do regime militar. Assim, dentro de uma reflexão sobre o desterro que utiliza como suporte teórico abordagens psicanalíticas, como a desenvolvida por Marcelo Viñar, e sociológicas, como a de Denise Rollemberg, exploram-se no presente trabalho o impacto e as consequências da violência do desenraizamento a partir dos personagens Fábio e Lázaro, jovens exilados em Paris.
\end{abstract}

\begin{abstract}
The XX century, considered by Eric Hobsbawm as the "Age of catastrophes", in Europe as much as in Latin America, was the stage where the cruelest acts of violence and authoritarianism performed their tragedies. The military dictatorship in Brazil committed hideous atrocities by the imposition of a political regime that banned freedom, imposed strict rules of behavior dictated by the state and punished individuals adverse to the rules of power in different ways, especially by the practice of exile. Ways of traumatic uprooting, in which the identity is denied through a brutal schism with the geographical, social and individual references; this is an experience connected to political processes that in the subjective dimension implies annihilations, fragmentation, disorientation, and identity crises. The novel Amores Exilados (2011), by Godofredo de Oliveira Neto, articulates imaginative writing and testimonial content to build a grounded narrative of the experiences suffered by the military regime's victims. Thus, in a reflection about the exile that uses as theoretical support psychoanalytic approaches, as developed by Marcelo Viñar, and sociological ones, as developed by Denise Rollemberg, I explore in the present work the impact and consequences of the violence of uprooting in the lives of the characters Fábio and Lázaro, youths exiled in Paris.
\end{abstract}

Keywords: Exile; identity; loneliness.

Palavras-chave: Exílio; identidade; solidão.

O século XX, considerado por Eric Hobsbawn como a "era das catástrofes" (1995, p. 112), tanto na Europa quanto na América Latina, foi o palco onde as mais cruéis experiências de violência e autoritarismo encenaram suas tragédias. Regimes políticos autoritários baniram das sociedades a liberdade e impuseram normas rígidas de comportamento regidas pelo Estado, reprimindo, assim, toda manifestação contrária às regras de poder. Dentro desse contexto, sobressai-se o Brasil, no período que abrange a ditadura militar (1964-1985).

\footnotetext{
*Formada em Letras- Língua Portuguesa e respectivas literaturas pela UNIJUÍ. Mestre em Literatura Brasileira pela UFRGS. Doutoranda em Literatura Brasileira pela UFRGS, bolsista Capes, participa do Grupo de Pesquisa denominado Literatura Brasileira Contemporânea: diálogos e reflexões.
} 
Durante os anos de chumbo desse regime foram estabelecidas políticas de extermínio e perseguição ideológica aos opositores, suprimiram-se direitos arduamente conquistados ao longo da história civil nacional, praticou-se tortura sistemática e censura indiscriminada. $\mathrm{O}$ clima de repressão brutal impeliu um grande contingente de pessoas ao exílio, devido à impossibilidade de exercer a profissão, de atuar politicamente ou simplesmente pela dificuldade de viver em um país que suprimiu a liberdade; os indivíduos ameaçados foram expulsos ou optaram por abandonar território nacional e buscar abrigo em países como o Chile e França.

O romance de Godofredo de Oliveira Neto, publicado originalmente com o título Pedaço de Santo (1997) e depois alterado para Amores exilados ${ }^{l}$ (2011), retrata a aflição dos jovens brasileiros exilados em Paris, justamente no tenso período dos fins dos anos 60 e princípios dos anos 70. A narrativa ganha forma através do entrecruzamento de quatro personagens principais: Fábio e Lázaro, militantes forçados a partir em virtude da repressão desenvolvida pelo regime militar; Muriel Melusina, jovem francesa mestranda em literatura e a Aliança Socialista Libertadora (ASL), grupo representante das diferentes organizações políticas de extrema esquerda que conseguiram se desenvolver no exílio. Sob o prisma teórico, Neto dá voz à trotskystas que creem somente na revolução incessante e apresentam com rancor e frustração os pactos que não apenas degeneram as escolhas políticas, como também desgraçaram a revolução. Dessa forma, ao longo do enredo são denunciadas a criação do Partido Único em Cuba em 1971 e a traição do Chile e do MIR, dirigido por Salvador Allende.

Como o próprio título prenuncia, uma das linhas centrais que compõe a tessitura do romance é constituída pela problemática do exílio, experiência ligada a processos políticos que na dimensão subjetiva implica em aniquilamentos, fragmentações e crises identitárias. Ao articular escrita imaginativa e teor testemunhal, Neto constrói uma narrativa alicerçada sobre o sofrimento experimentado pelas vítimas do regime militar. Assim, dentro de uma reflexão sobre o desterro que utiliza como suporte teórico abordagens psicanalíticas, como a desenvolvida por Marcelo Viñar, e sociológicas, como a de Denise Rollemberg, exploram-se no presente trabalho o impacto e as consequências da violência do desenraizamento a partir dos personagens Fábio e Lázaro.

\section{Breve reflexão sobre o exílio}

\footnotetext{
${ }^{1}$ Conforme entrevista do autor, a troca do título ocorreu apenas em razão da adaptação da narrativa para o cinema, visto que Pedaço de Santo sugeria o enforque maior para a figura do cotovelo de São Jorge, enquanto Amores exilados consegue transmitir a carga de complexidade do período mais bravo da ditadura militar. O texto não sofreu nenhuma alteração em nível de conteúdo ou estrutura.
} 
Desterrado, expatriado, degredado, afastado, banido... Muitos são os sinônimos para o vocábulo exilado, entretanto, nenhum é capaz de traduzir simplificadamente a dimensão traumática dessa experiência. É claro que, quando nos referirmos ao exílio, neste trabalho, não o estaremos considerando como um ato voluntário de isolamento do convívio social. Ao contrário, o concebemos como a ação de banir alguém de sua pátria, de expulsar, arrancar de suas raízes e mandar para longe, o que a caracteriza como uma prática coercitiva determinada por um poder externo, no caso, o poder de Estado. Portanto, um ato de violência e uma forma radical de exclusão política, produto da intolerância e dominação.

Maria Victoria Martínez (2007) esclarece que o termo exílio deriva etimologicamente do latim exsilium ou exilium, denotando pessoa banida. Assim, ele teria sido utilizado, especialmente entre 1220 e 1250, para designar os desterrados por ordem real, "por manifesta hostilidade do poder" (MARTÍNEZ, 2007, p. 14). Mesmo que o exílio não seja imposto expressamente, ele sempre está relacionado à pressão de uma força exterior, seja de um regime governamental, seja de uma forma determinada de política, seja uma ameaça concreta à vida. De modo inevitável ele acarreta "a perda total de referências políticas e do direito de pertencer a algum tipo de comunidade organizada, a privação do espaço da ação e do discurso e, consequentemente, a negação da possibilidade de luta pela liberdade" (GRECO, 2003. p. 153).

Logo, "exilado" e "desterrado" são lexemas de etimologia próxima, pois dizem respeito "à perda de algo próprio ou que pertence naturalmente à pessoa: a terra, a pátria, o país natal, o lugar de origem" (MARTÍNEZ, 2007, p. 14-15). Emblema da condição humana, desde a experiência primordial de Adão e Eva, é um tema recorrente e apresenta diferentes representações em todos os períodos históricos. Problema de várias faces, caracteriza-se como arquétipo da cultura Ocidental, sendo "irremediavelmente secular e insuportavelmente histórico, é produzido por seres humanos para outros seres humanos, é uma condição criada para negar a dignidade e a identidade das pessoas" (SAID, 2003, p. 47).

Nega-se a identidade através da ruptura com os referenciais geográficos, sociais e individuais, como expõe o psicanalista uruguaio Marcelo Viñar:

O homem se constrói a partir de suas ilusões e de seus projetos, e uma das dimensões da existência é o fato de remodelar permanentemente este jogo de ilusões e de projetos, que se dá entre o ser e as pessoas de sua convivência. O exílio faz abortar este movimento e o destrói, para retomá-lo na estranheza do não-familiar. Daí sua dimensão de traumatismo. Ele se apresenta como um tempo de inércia e contemplação, que emerge após a tormenta, o naufrágio e a catástrofe: propõe o desafio do que podemos construir a partir da perda, da desilusão, do desencorajamento, da derrota (VIÑAR, 1992, p.111) (grifos nossos) 
Superar o trauma e juntar os estilhaços que restaram depois da catástrofe são árduas tarefas que, não raras vezes, desencadeiam crises e instabilidades que são potencializadas pelo afastamento da língua, pela ausência da família e pelo sentimento de provisoriedade permanente. Embora esteja repleto de aspectos negativos, concebido como uma experiência de choque capaz de despedaçar subjetivamente o indivíduo, o desterro é ambíguo, paradoxal. Se de um lado há ruptura, rejeição e renúncia, de outro ele incita à força a capacidade imaginativa e criadora daquele que o experimenta, implicando, também, "sutura, reconstrução e recomeço" (QUEIROZ, 1998, p. 7). Portanto, caracterizado por Denise Rollemberg (1999, p. 24), como a "negação da negação, a luta pela afirmação, a resistência [...] vitória ante as adversidades, o triunfo da resistência, a derrota da exclusão, a solidariedade dos que acolhem os expulsos, dos que tomam seu partido".

\section{Estilhaçamento}

Uma imagem frequente quando se refere aos exilados é a do desenraizado, aquele que foi arrancado pelas raízes e/ou aquele que as perdeu. As raízes ligam o ser vivo à fonte mantenedora, aos componentes que se convertem para integrar o conjunto de sua matéria. Essa metáfora "indica o que é rompido no dilaceramento do exílio e que situa o sofrimento no centro do tema: dor de estar separado de suas raízes, distanciado das representações familiares" (VIÑAR, 1992, p. 111).

Os indivíduos vitimados pelo desenraizamento, como plantas arrancadas e jogadas em um espaço desconhecido, expostas às intempéries climáticas, ficam sensíveis, frágeis, desprotegidos dos elementos que transmitiam segurança, assim, têm toda a sua precariedade desnudada. A distância, a separação abrupta e a dor frente à impossibilidade de extrair os nutrientes necessários para a manutenção da vida desencadeiam uma série de sentimentos contraditórios que afetam não apenas as relações de pertencimento e de identidade, mas também passam a ser elementos constitutivos da sua rotina. O cotidiano dos desterrados, como demonstra Denise Rollemberg (1999, p. 132), é marcado pela “desorientação, as dúvidas, as certezas, as angústias, as mitificações, o vazio, o medo, a loucura, a morte, o gueto, a sobrevivência, o problema da documentação, o trabalho, o estudo, as transformações, a reconstrução de caminhos [...], enfim, as redefinições de identidade". Todos esses elementos expressos são encontrados do início ao fim dos 40 capítulos que compõe o romance Amores Exilados, e alguns desses pontos serão analisados a partir de agora.

O poder extremo que resultou no exílio em Paris dos personagens Fábio e Lázaro foi a ditadura militar brasileira. A trajetória que provocou o degredo de ambos é semelhante: 
motivados pelo desejo de um país mais justo, sem desigualdade social, tornaram-se militantes da ASL durante o período que estavam na faculdade (UFSC e UFBa, respectivamente). Ao participarem (cada um na sua região) de uma expropriação bancária que resultou em mortos civis, foram exilados. Entretanto, Fábio carrega a culpa de ter atirado e matado um homem durante o assalto, é preso, torturado ${ }^{2}$, consegue fugir da cadeia, é um exilado oficial. Já Lázaro não tem certeza se foi o seu tiro que matou um civil. O insucesso da expropriação em que participou causou grande agitação e para sua segurança a organização o mandou para a França.

Na Europa, afastados de todos os símbolos nacionais e dos elementos geográficos, temporais e espaciais que contribuem para a constituição subjetiva da identidade, resta apenas a aparência física como indício revelador de pertencimento à terra natal. Neste aspecto, Fábio Antônio Nunes dos Santos, natural de Florianópolis, permanece em desvantagem em relação aos outros companheiros. Os próprios amigos brasileiros não o consideram fisicamente como um representante nacional "Você tem cara de italiano do Norte, ou austríaco, Fábio, esse cabelo castanho claro, liso até os ombros, olhos azuis, rosto fino, cara de Cristo tirolês, pode crer, não parece brasileiro, nego véio! Eu e o Lázaro, sim” (NETO, 2011, p. 11). Em contraposição, Lázaro da Costa Costa é considerado pelos outros como um típico brasileiro: arrebatador de corações, chamado pelas mulheres por Doce Caramelo, de "jeitão bem baiano, sempre dando a impressão de sentia menos falta do socialismo utópico do que do acarajé, conseguia mesmo seduzir" (NETO, 2011, p. 11).

O jogo parecer e pertencer incomoda profundamente o catarinense, além de ter sido arrancado da terra, ele não herdou os traços genéticos que permitem o reconhecimento: brasileiro com cara de italiano. O jovem busca convencer os outros, em especial a sua namorada, que a alma do Brasil negra e baiana não passa de uma "imagem de atração turística pro Hemisfério Norte" (NETO, 2011, p. 46) construída a partir de um processo artificial que encobre a história oficial sobre as fontes africanas na formação da nação. Tentativa frustrada, pois Muriel mesmo tendo morado em diferentes regiões brasileiras acredita que "a Bahia é mais Brasil do que o Sul. A comida, as cerimônias religiosas, os baianos parecem que são a alma brasileira. E o Brasil é um país negro” (NETO, 2011, p. 45). Assim, Neto expõe que a própria representação da terra carrega o peso da separação entre norte e sul; a cisão é um elemento identitário inerente, na qual a imagem do norte prevalece.

\footnotetext{
${ }^{2}$ Sobre a problemática entre memória, trauma e tortura a partir desse personagem ver o artigo, desenvolvido pela professora doutora Gínia Maria Gomes (UFRGS).
} 
Produto de uma terra cindida, Fábio, antes mesmo de ser arrancado do Brasil, quando recebe as passagens para o exílio, depara-se com a emblemática fotografia de uma mulher cortada ao meio:

Glorinha trouxe a passagem Rio/Buenos Aires, de ônibus, no prospecto aparecia uma mulher cortada ao meio, na vertical, metade usando biquíni, a outra vestida com um grande sobretudo de lã, era assim que eu via as pessoas, duas ao mesmo tempo, eu dois [...] argentino e brasileiros, todos ali eram rachados ao meio. (NETO, 2011, p. 124)

O prospecto que desencadeia o processo de ver todas as pessoas rachadas é o reflexo da própria condição de exilado: ser dois ao mesmo tempo, pertencer a uma terra e estar em outra. Conforme Said (2003, p. 46) esta experiência "é terrível de vivenciar. Ele é uma fratura incurável entre um ser humano e um lugar natal, entre um eu e seu verdadeiro lar. Sua tristeza essencial jamais pode ser superada". Logo, qualquer sucesso e/ou realização em terra estrangeira sempre será permeado pela perda de algo deixado para trás.

A complexa situação de ser dois em um só corpo e de estar impedido de regressar à terra natal provocam no desenraizado um turbilhão de sentimentos que oscilam entre polos contrários em relação ao país que o abriga, como é possível constatar na seguinte exposição do narrador em terceira pessoa: “A solidão em alguns, a estranha alegria em outros, a angústia na maioria. $\mathrm{O}$ universo dos exilados era esse. A insegurança psicológica ou levava a abraçar com exagerado ardor o país do exílio ou a abominá-lo" (NETO, 2011, p. 51).

É relevante mencionarmos que, enquanto vive no exterior, o país de origem que o exilado retém consigo passa por um processo de idealização nostálgica, conforme Viñar (1992, p.112), ou seja, a imagem inalterada da data de partida sofre os efeitos da distância e da memória, podendo levá-lo a amenizar sofrimentos, negações e perdas, e a transformar sua pátria imaginária no melhor lugar do mundo. De acordo com Rollemberg (1999), nascem daí outras dificuldades perceptíveis na relação do exilado com o país de acolhida que alimentam o crescente desejo de voltar.

No romance em questão, o responsável por construir uma imagem nostálgica do país de origem é Fábio. O sol forte e o mar, ilustração congelada nos selos das cartas que recebe, caracterizam o Brasil, em especial as praias catarinenses: “Os selos eram azuis, com a ponte Hercílio da Luz e a capital catarinense ao fundo. O mar e o céu de sua infância se confundiam" (NETO, 2011, p. 87); "O sol nas dunas das praias da ilha de Santa Catarina, o reflexo na lagoa da Conceição" (NETO, 2011, p. 161). Em contraposição, nas descrições sobre Paris imperam sempre os tons negativos, sombrios: "Paris escondia-se sob uma névoa 
rala. Talvez fosse esse céu esbranquiçado passando a chumbo que afogava as alegrias; que deprimia [...] impressão de se viver num casulo de asfalto" (NETO, 2011, p. 16).

Neste "casulo de asfalto", que aprisiona o ser no presente, longe do ambiente paradisíaco do passado, até mesmo a natureza é apresentada pelo seu viés cruel e sanguinário; pois na floresta da cidade de Senlis, onde os militantes caminham depois de um almoço na casa de um companheiro, veem "na mata, uma corça ferida, arrastando uma das patas traseiras na tentativa de correr, e deixando um rastro vermelho" (NETO, 2011, p. 29). O mal estar diante do animal ferido é semelhante ao que o catarinense tem frente à disputa por alimentos entre corvos e pássaros na praça:

Com a neve, os pássaros se aproximavam em busca de comida, pareciam doentes, as penas arrepiadas. [...] Os pássaros disputavam a comida; quando chegava um corvo, ela espantava-o aos gritos. Fábio estreitava Muriel contra o seu peito e tentava beijá-la.[...]. ' É, melhor olhar os pássaros, Fábio, olha como os pintarroxos têm medo dos corvos. Mas todos sabem voar'. (NETO, 2011, p. 158).

Notemos que a degradação física e comportamental dos pássaros ocasionada pelo clima afeta o personagem a ponto de voltar a sua atenção somente para a amada. É possível afirmar que a metáfora utilizada por Muriel é o ícone do momento de repressão política pelo qual passam os membros da ASL: os pequenos pintarroxos, assim como os militantes de esquerda, são perseguidos pelos corvos, estes podem ser os repressores da ditadura militar; porém numa perspectiva otimista todos "sabem voar", o que sugere a liberdade, isto é, mesmo perseguidos e expulsos da terra natal o abrigo sempre será ofertado em outro espaço. Dessa forma, a jovem francesa aparentemente procura estimular o namorado a reunir forças para superar o impacto da separação e assim continuar vivendo.

Logo após a chegada à Europa, Rollemberg (1999, p. 64) explica que o exilado político transformava-se no refugiado, naquele que precisa receber assistência. Isso faz com que o país de acolhida relacione-se de modo infantilizado com o estrangeiro que passa a viver entre a "necessidade e o constrangimento", se de um lado há a complacência de outro há a cobrança. Esse desconforto também atinge os militantes da ASL, os quais durantes as reuniões apresentam concepções divergentes sobre a França: enquanto uns a consideram como o "berço da tolerância" (NETO, 2011, p. 51), em razão das lutas do povo através dos tempos; outros têm contato direto com a "frieza" e com o "mau humor" (NETO, 2011, p.51) dos franceses que os hostilizam com olhares ameaçadores, com a falta de diálogo nos vagões dos trens ou até mesmo com críticas diretas como a seguinte: "Elevador parado. 'Quebrou, excesso de peso, estrangeiros em demasia morando nesses prédios', alguém comentou”. (NETO, 2011, p. 12). 
Longe de casa, muitas vezes sem o contato com os familiares, em um país estranho, obrigado a reconfigurar os projetos e a redefinir sua identidade, a solidão torna-se um espectro que aterroriza o cotidiano no exílio. Os desenraizados vivenciam um verdadeiro "pânico da solidão" (ROLLEMBERG, 1999, p. 136), desejam pertencer a algo que encubra, mesmo que provisoriamente, a precariedade de estar só. Em algumas reuniões da ASL o medo de ficar sozinho é perceptível através da composição dos integrantes que não estão envolvidos com a causa, portanto longe de serem militantes, configuram-se apenas como companhia; visto que há a presença de diferentes nacionalidades, como alemães, árabes e até mesmo "dois argelinos vizinhos de Lázaro que não tinham nada a ver com nada mas que frequentavam com assiduidade aquela casa sabe-se lá por quê. O próprio Lázaro, talvez para fugir da solidão, os convidasse" (NETO, 2011, p. 10).

O medo de ficar sozinho faz com que os sujeitos se relacionem quase que desesperadamente com as pessoas que se aproximam. Assim acontece com Fábio, que vê em Muriel a sua salvação: “Quero ter um filho com você, Muriel, se for menina vou dar o nome de Stênia. Não quero mais ficar sozinho, nunca mais. Aqueles cachorros nojentos dos torturadores quase acabaram comigo, mas agora estamos aqui juntos" (NETO, 2011, p. 78).

Muriel é uma sedutora estudante francesa que evita tecer comentários a respeito de sua infância, não responde as insistentes perguntas do namorado sobre o tempo distante, vive o presente e cala sua história pregressa. Se Fábio foi expulso de sua terra natal ela cortou definitivamente as suas raízes com o passado. $\mathrm{O}$ ar de mistério, de enigma a ser decifrado perturba o militante catarinense que a chama de Melusina. Esta é a protagonista do conto francês $O$ romance de Melusina ou A história dos Lusignan, de Jean D’Arras, misto de feiticeira e fada que se transformava em sereia constantemente, devido a uma maldição que só seria quebrada por um marido que jamais soubesse do segredo. Casa-se com Guy de Lusignan, Conde de Poitou, sob a condição de que ele nunca tentasse invadir sua privacidade, entretanto o marido curioso espiona a mulher tomando banho e a descobre em sua forma de sereia. Como castigo ela o transforma em dragão e nunca mais é vista por olhos mortais.

Há pontos em comum entre a Melusina de Neto e a de D'Arrais. Ambas encobrem segredos, têm companheiros curiosos e simplesmente desaparecem. Durante os banhos de Muriel na banheira, o catarinense imagina uma "misteriosa cauda" (NETO, 2011, p. 101) que inicia logo depois da cintura, isso a aproxima ainda mais da personagem lendária. A estudante francesa teve um relacionamento amoroso com Lázaro e a estranha relação mantida entre os dois depois do fim do namoro faz com que Fábio seja atormentado por um ciúme doentio, 
desconfie da fidelidade de sua amada, questione o amigo sobre a permanência do envolvimento, e persiga-a pelas ruas de Paris

Sem exercer propriamente um trabalho no país estrangeiro, sobrevivendo de uma bolsa de ajuda de custo, Fábio realizava alguns estudos e participava assiduamente das reuniões da ASL. Dessa forma, as forças do militante são canalizadas ora para a relação amorosa ora para a organização. A namorada é o vínculo afetivo mais forte, o pilar que sustenta a sanidade mental do mesmo, porém o clima tenso produzido pelas notícias aterrorizadoras de companheiros caídos no Brasil juntamente com o trauma, tanto da tortura quanto do exílio, são potencializados pela insegurança diante da volúpia da namorada; desestabilizam o catarinense que não tem mais tranquilidade e é tomado por um período de intensa agitação emocional amparado pela bebida alcoólica. O atordoamento psicológico atinge o ápice depois que Sarinha, nova líder da organização, expulsa Muriel de uma reunião, em razão do comportamento provocativo da francesa, a qual sai acompanhada por Lázaro. O fato de demorar em encontrá-los faz Fábio crer que os dois estão o traindo, após localizá-los, a companheira é punida fisicamente:

A cauda imaginária parecia que tinha aumentado de tamanho. Era um rabo de bichão grande! Fábio deixou-se nessa posição e foi até o quarto. Abriu a bolsa encardida e segurou a caixa que levava sempre consigo. Abriu-a cuidadosamente. [...] Fábio segurou o amuleto de madeira com habilidade, cuidando para que a parte que tinha uma pequena lasca ficasse para frente, como o cano de um revólver. Muriel Melusina continuava de bruços, sempre meneando lentamente o rabo imaginário. [...] Não levantava os olhos de um mundo que só ela enxergava. Fábio ajoelhou-se ao lado da banheira e, brutalmente, sem emitir um único som, enfiou o pedaço de madeira onde fincava raízes a cauda maldita! Aquela mulher, agora um monstro de pecado, urrou de dor, levantou de um salto, e bateu furiosamente com a mão fechada no rosto do torturador. (NETO, 2011, p. 131)

Possuído pelo ódio, Fábio fere a amada justamente no local de onde emana a força da sedução. Armado com o cotovelo de madeira do santo São Jorge (presente do pai), simbolicamente, ele ataca a origem de todo o mal: a "cauda". A desestruturação emocional que domina o personagem, mais uma das consequências do exílio, é considerada por Rollemberg (1999, p. 137) como a grande responsável pelo término de muitas uniões conjugais em tempos de desterro, já que "Em meio à perda de referências e às dificuldades do período de reconstrução, o desgaste é inevitável”.

Neto traça a trajetória do amor que se converte em ciúme para materializar-se em violência. Este percurso altera as posições dos sujeitos, isto é, o militante torturado passa a ser o carrasco: um insano motivado pelo desejo de posse, aterrorizado pela possibilidade de mais uma perda. A atitude demente de Fábio é perfeitamente verossímil se considerarmos que conforme Viñar (1992, p. 114) o exílio é um acontecimento traumático capaz de desnudar, 
desmarcarar e intensificar "o louco que cada um carrega em si. [...] coloca[ndo] em relevo as qualidades e os defeitos de nossa condição de humanos, amplificando-os”. Despidos dos véus que protegem a identidade, os sujeitos têm seus traços de personalidade desvelados, logo não é somente o catarinense que passa por períodos de instabilidade psicológica. Era comum durante os encontros da Aliança os militantes passarem "Da raiva ao ódio, do ódio ao ataque, deste à defesa, da defesa à condescendência, desta ao choro” (NETO, 2011, p. 133).

Lázaro também tem determinadas características acentuadas de modo que destoe dos padrões convencionais. Engajado na causa pela justiça social, durante a faculdade, separava boa parte de seu tempo para estudar Marx, Engels, Che Guevara, Trotski. Entretanto, no exílio, estimulado pelo contato com uma namorada médica e psicóloga amplia seus estudos para a psicanálise. O vocabulário aumenta e as áreas embaralham-se, o que é encarado com desconfiança: “ 'anda misturando bobó e xinxim com wunschphantasien, assim mesmo em alemão, já pensou, Muriel? [...] Ontem ele me disse na despedida: Lê Le Balcon, do Jean Genet, ô Catarina, é um tratado sobre o caralho! [...] Acho que ele está ficando meio doido' " (NETO, 2011, p. 23).

O alto poder de sedução é outra característica de Lázaro que longe das origens é amplificada. Por meio do corpo escultural do baiano (capaz de fazer as mulheres de qualquer idade tremerem de desejo) e das "investidas donjuanescas" (NETO, 2011, p. 93) conquistou diferentes lugares sociais: desde o ingresso para a ASL, passando pela redação do Le Monde até a matrícula no curso de Sociologia pela Sorbonne-Paris III, todos esses espaços foram mediados por mulheres, uma espécie prêmio pelos favores sexuais. Contudo, a beleza e a inteligência em momento algum são garantia de integração, o sentimento de nãopertencimento e de inadequação ao espaço não podem ser amenizados com a satisfação carnal:

- O pessoal daqui não gosta de mim, Fábio!

- Não gosta como? E as mulheres que você tem?

- São estrangeiras. (NETO, 2011, p. 97)

Nenhuma mulher é capaz de preencher o vazio deixado pelo desterro, até mesmo porque, nas próprias palavras de Lázaro, todas “são estrangeiras". Através desse personagem Neto expõe outro dilema comum da vida no exílio: o problema da documentação. Como mencionado anteriormente, o baiano não era um exilado oficial, vivia de forma clandestina na França, visto que seu passaporte tinha sido carimbado apenas para entrar na Itália. Até determinado momento ${ }^{3}$, aparentemente, o militante não havia sentido a necessidade de obter

\footnotetext{
${ }^{3}$ Mais precisamente no capítulo número 13.
} 
os documentos, trabalhava na redação do Le Monde. Rollemberg (1999, p. 158) defende que foi sintomática entre os exilados certa resistência em legalizar sua situação, o que revelava o anseio em "preservar o passado e, portanto, uma identidade", ao adquirir novos documentos deixava para trás a nacionalidade, o projeto de volta e da guerrilha.

No entanto, com o crescente clima de insegurança reforçado por meio das notícias vindas do Brasil que traziam o ar de derrota é que Lázaro desespera-se. Durante o velório de um companheiro do PTU (Partido Trabalhista Unificado) não consegue conter as lágrimas, chora e berra todo seu tormento: “- Eu vou ser preso, porra, eu vou ser preso! E ninguém aqui vai se preocupar com isso, eu sei muito bem. Aqui só tem branco ou mulato com alma de branco. Eu sou negro!” (NETO, 2011, p. 96). Embora fosse um grande conquistador, é a aliança que organiza um casamento com "Farida. Argelina de origem, porém detentora de uma Carte Nacionale d'Identité e de um passaporte da França" (NETO, 2011, p. 99), a qual aceita a proposta mediante o pagamento de dois mil e quinhentos francos e sob a confirmação de que a família do baiano tinha posses. O casamento tem duração de dois meses, depois dos quais a esposa cansa-se do marido "cachaceiro, mulherengo e sempre ausente" (NETO, 2011, p. 100) e vai embora com um namorado, mas a nacionalidade francesa permanece com Lázaro.

A reestruturação da vida é uma tarefa paradoxal, uma vez que a reconfiguração dos projetos de vida implica em mudança de identidade, deixar a parte de si que ficou no país de origem para construir um novo "eu" em solo estrangeiro. Mas qual caminho seguir? Continuar a lutar por um país melhor ou optar por um projeto individual? A realização pessoal é possível longe de casa? A dúvida acomete tanto Fábio quanto Lázaro, que inúmeras vezes questionam-se sobre os rumos artificiais que a vida política seguiu. Percebem que a verdadeira essência que os motivava a lutar sofreu a ação do tempo e está desgastada:

[...] Já pensei mil vezes em largar tudo e ter uma vida com Muriel. [...] Os nossos diálogos, por exemplo, Lázaro, principalmente quando tratam de assunto político, parecem falsos. Pode prestar atenção. É tudo meio decorado. Estou de saco cheio de representação. E farto de viver numa lapa. (NETO, 2011, p. 62)

- Penso, mano, que, no fim, é melhor mesmo a ideia de frentes populares. Fiz aquele discurso porque é o que todos da ASL esperavam, mas no fundo acho que Allende estava certo, estou me sentindo meio apertado na ASL, não sei por quê! Tem gente dizendo que está tendo guerra em Tocantins, o Exercito tá descendo a porrada, não sei se é verdade. (NETO, 2011, p. 112) (grifos nossos)

As falas acima, do catarinense e do baiano, respectivamente, demonstram de modo singular o cotidiano no exílio, o qual Rollemberg (1999, p. 132) explica que foi marcado pelo constante "mal-estar em relação ao outro e, sobretudo, em relação a si mesmo, entre o que se era - ou se pretendia ser -, e o que se acabou sendo de fato. É a história da desorientação, da 
crise de valores". Identidades em conflito, Fábio e Lázaro contabilizam as perdas e ganhos, têm consciência da degradação política pela qual estão passando: antes militantes ativos na luta pelo fim da desigualdade social, agora marionetes que repetem um discurso préestabelecido. Não obstante, vivem alienados, a organização transmite uma mensagem política autoritária, desconhecem a veracidade das notícias que recebem.

Além da alienação gerada pela distância, os militantes, não raras às vezes, eram forçados a cumprir tarefas ditadas pela organização, com as quais nem sempre concordavam. O historiador Daniel Aarão Reis Filho (apud ROLLEMBERG, 1999, p. 140), ex-militante e ex-exilado político, explica que no exílio se desenvolveu o chamado "mito da terra", uma determinação propagada entre os militantes que no exterior (afastados da prática direta) não era possível opinar e tampouco decidir sobre as direções da luta. Cabia-lhes apenas a tarefa de esperar e obedecer aos rumos vindos "da terra", de quem estava ativo na prática. Essa situação também é ilustrada no romance, especialmente quando Fábio e Lázaro são forçados a regressar: "Novos planos de ação se impunham. Chegaram ordens do comando da ASL, em São Paulo: volta clandestina ao Brasil para obtenção de fundos. Fábio e Lázaro viajariam. Eram os únicos que tinham experiência de expropriação bancária” (NETO, 2011, p. 139-140).

Os comandos vêm de fora, são emitidos por vozes legitimadas, ativas na luta. Os jovens brasileiros tentam argumentar contra, mesmo desejando muito voltar para a terra de origem não estão preparados psicologicamente para regressarem de forma ilegal, discordam com o caráter autoritário da ordem: “-Não é assim, não! Vai e pronto!” (NETO, 2011, p. 140). Divergem dos métodos e da prática adotada, não querem fazer a mesma coisa que lhes causou o desterro: expropriação bancária. Agora, pelas mãos da ASL, justamente de quem lhes ofereceu abrigo, são forçados a deixar para trás, novamente, tudo o que estavam conseguindo conquistar: a nova identidade, as novas relações afetivas, os novos projetos de vida. As tenras raízes que despontavam são cortadas de modo tirânico, Sarinha é austera em expor a impossibilidade de questionamento das decisões da aliança:

Mas quero também aqui deixar bem clara uma coisa: se isso fosse na ASL-Brasil não haveria
essa discussão toda. As ordens são para serem cumpridas e pronto. Há uma indisciplina muito
grande na ASL-Paris. Às vezes parece uma zona. (NETO, 2011, p. 141-142) (grifos nossos)

Fábio e Lázaro cedem tanto pela pressão/unanimidade do grupo quanto pela sedução que a oportunidade de regressar lhes propicia. No entanto, longe do retorno trazer alívio, ele causa inquietação. Durante o regresso, quando passam pelo Peru e Bolívia, ambas as personagens são afetadas de forma distinta: o catarinense sofre com crises de enjoos, não sabe o que os provoca; enquanto o baiano tem dores de estômago e é assolado por complexo de 
rejeição, sente-se deslocado pela sua cor. Provavelmente são o medo e a expectativa da volta os responsáveis pelo desconforto físico e psicológico, os quais cedem espaço para o sentimento de estranhamento em solo brasileiro.

O psicanalista Viñar (1997, p. 115) esclarece que o "mito do retorno" é uma ilusão para o desenraizado, uma experiência ambígua, pois, "Retornar é também confrontar-se com a diferença e a alteridade, nisto que comportam de risco, de horror e de violência" (VIÑAR, 1992, p. 115). Regressar às origens causa uma sensação de deslocamento incômodo, ao mesmo tempo em que as personagens constatam diferenças entre o Brasil e Paris, procuram avaliar o atraso e o progresso de ambos os países. Embora ambientes como a rodoviária Novo Rio continuem decadentes, materialização da precariedade e falta de refinamento dos habitantes, "Um lixo. Não tinha camembert, nem bistrô, muito menos beaujoulais. Vendedor de mate, limonada, jujuba, ficha de telefone, mariola, loteria, amendoim torrado, cheiro de mijo e vomitado" (NETO, 2011, p. 175); será o modo de vida brasileiro superior ao europeu: "o que surpreendia [...] era a exuberância da qualidade de vida de grande parte da classe média. O país era, em vários aspectos, mais moderno que a Europa e as pessoas - mesmo de classe baixa - viviam com mais conforto que em Paris ou Londres” (NETO, 2011, p. 181).

No Rio de Janeiro, o clima festivo e ameno, identificado através de ensaios para gafieira, da tranquilidade das pessoas sorridentes que transitam pelas ruas e dos ônibus da cidade, nada condiz com a atmosfera tensa de ditatura que os militantes têm conhecimento no exterior. Retornar para uma realidade que aparentemente é bem oposta daquela de que se têm notícias causa não apenas estranhamento, mas crise. Fábio e Lázaro veem suas identidades se desmoronar: de militantes, engajados por uma luta de igualdade social e política, para ladrões clandestinos. Respirar ares conhecidos e ouvir o idioma materno em momento algum serve de alento diante da situação a que foram rebaixados:

[...] enfim, falaram em voltar, essa foi a vontade, retornar a Paris.

- Voltar para o Brasil, sim, mas não nessas condições. Se arriscar desse jeito? Fazer poética com arma de fogo; não pretendo ser o bardo viajante da ASL. Tanto tempo querendo ver e escutar esse país, cacete! Voltar como ladrão?

- Não, Lázaro, não é como ladrão, é obedecendo à organização.

- É sim, como ladrão; sem articulação com o movimento político, sem ligação com movimentos populares; ou volto para Paris ou me escondo na Bahia, mano, clandestinamente, morou? No meio do cacau, no Pelourinho, Itaparica, Monte Pascoal, em Katmandu, estou fora, meu chapa! E não vem com ordem de chefe de operações!

- A gente então devia ter dito antes, Lázaro.

- Estou dizendo agora.

- Então vamos voltar, porra, está bem! Eu vou procurar Muriel, viver a nova vida que já tinha escolhido. (NETO, 2011, p. 168) 
O sujeito já não pertence a lugar algum, na França o desejo era estar no Brasil, agora, em solo natal, o que os motiva é o anseio pela volta à Europa. Destituídos de qualquer raiz, a identidade anterior de estudantes não lhes é mais possível e as que dispõem nada lhes agradam, estão condenados a permanecer fora do lugar.

O exílio, ícone da condição humana, é uma das experiências mais devastadoras imposta pelos seres humanos. Ruptura cruel das raízes entre um ser humano e o seu solo de origem, entre o eu e sua pátria. Tal devastação é representada de modo ímpar em Amores Exilados através dos personagens Fábio e Lázaro, que como herdeiros do pecado original estão condenados a serem hóspedes temporários em qualquer lugar, estrangeiros até mesmo em sua terra natal. Ao articular escrita imaginativa e teor testemunhal, Godofredo de Oliveira Neto, constrói uma narrativa alicerçada sobre o sofrimento experimentado pelas vítimas do regime militar e demonstra que o exílio não é somente um estado físico, temporal e espacial, mas também um estado mental. O sentimento de perda das raízes desencadeia um turbilhão de outros sentimentos, geralmente contraditórios, como a solidão, a nostalgia, a exclusão, a precariedade, a vontade desesperada de construir vínculos e a triste constatação de que a identidade de outrora é inalcançável assim como a relação de pertencimento será afetada para sempre.

\section{Referências}

GRECO, Heloisa Amélia. Dimensões fundacionais da luta pela anistia. Tese de doutorado apresentada à FAFICH - UFMG. Belo Horizonte, 2003.

HOBSBAWM, Eric J. Era dos extremos - o breve século XX. São Paulo: Companhia das Letras, 1995.

MARTÍNEZ, Maria Victoria (org). Migraciones y escritura: pasado y futuro, lengua y nación. Córdoba: Univ. Nacional de Córdoba, 2007.

NETO, Godofredo de Oliveira. Amores exilados. Rio de Janeiro: Record, 2011. abril 2014.

. "Entrevista" < http://www.youtube.com/watch?v=klxbrJweXL4 > . Acesso em: 02 de

ROLLEMBERG, Denise. Exílio: entre raízes e radares. Rio de Janeiro: Record, 1999.

SAID, Edward. Reflexões sobre o exílio e outros ensaios. Tradução: Pedro Maria Soares. São Paulo: Companhia das Letras, 2003.

VIÑAR, Maren; e VIÑAR Marcelo. Exílio e tortura. São Paulo: Escuta, 1992. 